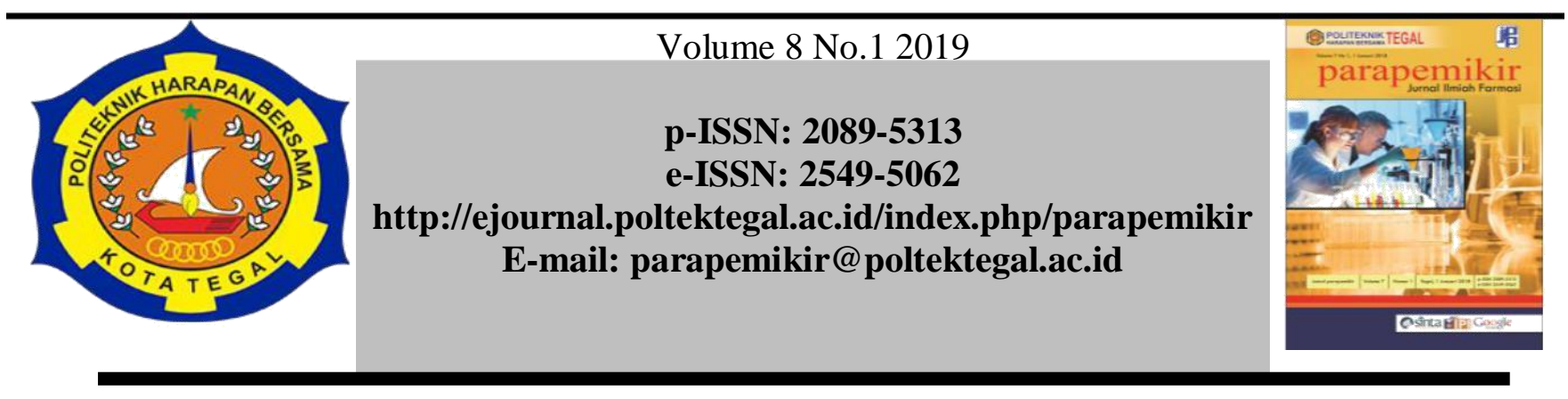

\title{
UJI IDENTIFIKASI BAKTERI Esherichia coli PADA JAMU GENDONG KUNYIT ASEM DI KABUPATEN TEGAL
}

\author{
Inur Tivani ${ }^{1}$, Wilda Amananti ${ }^{2}$, Ahmad Sunardi $^{3}$ \\ ${ }^{123}$ Politeknik Harapan Bersama Tegal; Jl. Mataram No. 09 Kota Tegal, Kodepos 52122 \\ Email : tiva.nie40@gmail.com
}

\begin{tabular}{|c|c|}
\hline Article Info & \\
\hline Article history: & \multirow{12}{*}{ 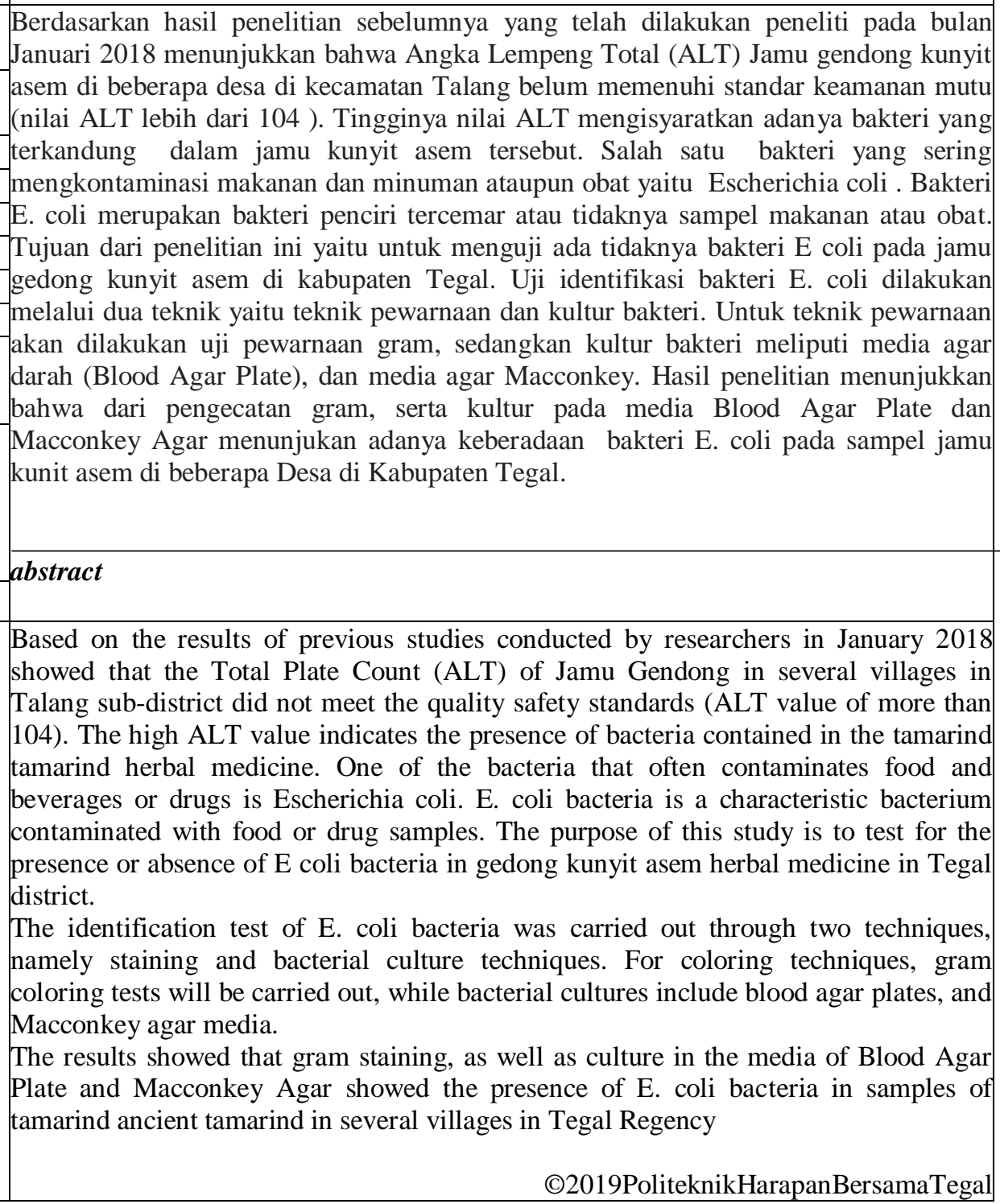 } \\
\hline & \\
\hline Received in & \\
\hline revis & \\
\hline Desember 2018 & \\
\hline Accepted Januari & \\
\hline 2019 & \\
\hline Available online & \\
\hline January 2019 & \\
\hline $\begin{array}{l}\text { Kata kunci: Uji } \\
\text { Identifikasi, Bakteri } \\
\text { Escherichia coli, } \\
\text { Jamu gendong, }\end{array}$ & \\
\hline kunyit asem. & \\
\hline & \\
\hline
\end{tabular}


Inur Tivani, Wilda Amananti, dan Ahmad Sunardi, Vol 8 (1) 2019 pp 31-35

Alamat korespondensi:

Prodi DIII Farmasi Politeknik Harapan Bersama Tegal

Gedung A Lt.3. Kampus 1

Jl. Mataram No. 09 Kota Tegal, Kodepos 52122

Telp. (0283) 352000

p-ISSN: 2089-5313

E-mail: parapemikir_poltek@yahoo.com

e-ISSN: 2549-5062 


\section{Pendahuluan}

Zaman modern yang penuh dengan kemudahan hidup tak berbanding lurus dengan munculnya berbagai penyakit di muka bumi. Semakin hari semakin banyak manusia terinfeksi berbagai macam penyakit. Pengobatan menjadi salah satu jalan menuju kesembuhan. Sebagian dari masyarakat masih memilih untuk menggunakan obat-obatan kimia. Sebagian yang lain, banyak pula masyarakat yang beralih menggunakan obat alam karena dipandang lebih aman dan tak beresiko efek samping. Dengan berbagai alasan sepeti lebih murah serta aman itulah yang membuat masyarakat pedesaan khususnya banyak mengkonsumsi obat herbal. Salah satu obat herbal yaitu jamu. Berbagai macam jamu banyak beredaran pasaran. Salah satu jamu yang masih dijajakan di beberapa desa di kabupaten Tegal yaitu jamu gendong. Jamu gendong kunyit asem merupakan jamu yang paling laris diserbu konsumen di daerah ini.

Peraturan pemerintah menyatakan bahwa perlu dicegah beredarnya obat tradisional yang tidak memenuhi persyaratan keamanan, kemanfaatan dan mutu[1]. Parameter keamanan meliputi uji cemaran mikroorganisme seperti uji mikroorganisme patogen, uji Angka Lempeng Total, uji Angka Kapang/Khamir, uji aflatoksin serta uji cemaran logam berat [2]

Berdasarkan hasil penelitian sebelumnya yang telah dilakukan peneliti pada bulan Januari 2018 menunjukkan bahwa Angka Lempeng Total (ALT) Jamu Gendong kunyit asem di beberapa desa di kecamatan Talang belum memenuhi standar keamanan mutu (nilai ALT lebih dari 104 )[3]. Tingginya nilai ALT mengisyaratkan adanya bakteri yang terkandung dalam jamu kunyit asem tersebut. Beberapa bakteri yang sering mengkontaminasi makanan dan minuman ataupun obat antara lain Escherichia oli, Staphyloocus aureus, Salmonella typhosa, Vibrio cholera, Clostridium perfringents, Bacillus ereus, dan Pseudomonas aeruginosa [4]

Bakteri E. coli merupakan bakteri penciri tercemar atau tidaknya sampel makanan atau obat. Keberadaan bakteri ini akan menyebabkan berbagai penyakit salah satunya yaitu diare. Berdasarkan hal tersebut, maka peneliti tertarik untuk mengidentifikasi keberadaan bakteri E. coli yang terkandung dalam jamu gendong kunyit asam di beberapa desa di kabupaten Tegal. Uji identifikasi yang akan dilakukan meliputi uji teknik pewarnaan dan kultur bakteri. Untuk teknik pewarnaan ada uji pewarnaan gram sedangkan kultur bakteri meliputi media agar darah (Blood Agar Plate), dan media agar Macconkey.

\section{Metodologi Penelitian}

Penelitian ini merupakan penelitian non eksperimental deskriptif yaitu mendeskripsikan hasil identifikasi bakteri E. coli pada jamu gendong di Kabupaten Tegal

Pengambilan sampel jamu kunyit asem ilakukan pada pukul 06.00 pagi dikarenakan pada jam tersebut para penjual jamu baru memulai menjajakan dagangannya. Pengambilan sampel ilakukan di beberapa desa di kabupaten Tegal. Wilayah yang diambil yaitu kecamatan adiwerna, kecamatan kramat, kecamatan dukuhturi dan kecamatan Talang. Sampel jamu yang diambil dimasukan ke dalam botol vial yang telah disterilkan terlebih ahulu selanjutnya dimasukan dalam cool box yang sudah disterilkan pula. Tujuannya agar sampel tiak terkontaminasi dengan lingkungan sekitar selama perjalanan ke laboratorium polteknik harapan bersama tegal.

a. Pewarnaan Gram

Pewarnaan gram dilakukan dengan cara menyiapkan media yang telah berisi sampel. Langkah-langkah pearaan gram sebagai berikut [5]:

1. Bersihkan gelas benda dengan alkohol hingga bebas lemak

2. Buatlah olesan bakteri pada gelas benda tersebut

3. Kering anginkan dan kemudian fiksasi dengan pemanasan

4. Bubuhi secara merata olesan tersebut dengan kristal violet (Gram A) dan biarkan selama 30 detik, kemudian cuci sampai bersih dengan air mengalir

5. Bubuhi merata dengan larutan iodine (Gram B, larutan mordan), biarkan selama satu menit, kemudian cuci dengan air mengalir

6. Tuangi dengan etil alkohol 93\% (Gram C) selama 15 - 25 detik untuk dekolorisasi (penghilangan cat). Dekolorisasi telah terjadi dan berakhir ketika aliran solvent (etil alkohol) menjadi tidak berwarna lagi. Selanjutnya cuci bersih dengan air mengalir

7. Bubuhi dengan safranin (Gram D) selama 45 detik.

8. Cuci dengan air mengalir dan kering anginkan atau keringkan dengan kertas penghisap

9. Pengamatan dengan mikroskop cahaya

b. Penanaman/ kultur pada Media Blood Agar Plate (BAP) dan pada Media Macconkey Agar

Penanaman bakteri pada media Blood Agar Plate dan Maconke Agar dilakukan dengan membuat pengeneran terlebih dahulu terhadap sampel dengan menggunakan pengeneran 10-3 selanjutnya dilakukan kultivasi dengan metode spread plate. Langkah selanjutnya diinkubasi hingga $4-48$ jam. Amati hasil yang terbentk dari penanaman tersebut. 


\section{HASIL DAN PEMBAHASAN}

3.1 Hasil Uji Pewarnaan Gram

a. Sampel 1 (Desa Langgen)

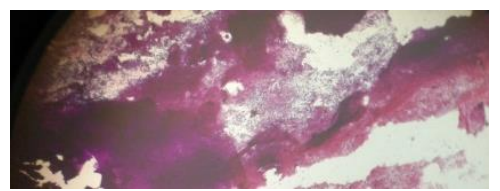

Gambar 1

Hasil Pewarnaan Gram Sampel 1

b. Sampel 2 (Desa Debong)

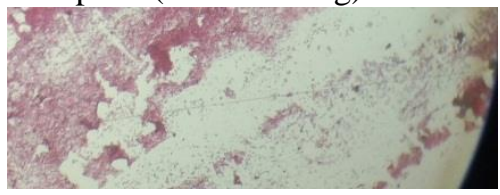

Gambar 2.

Hasil Pewarnaan Gram Sampel 2

c. Sampel 3 (Desa Kertayasa)

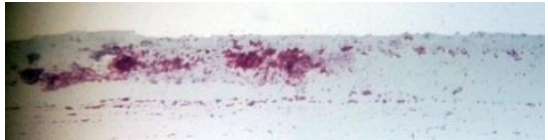

Gambar 3.

Hasil Pewarnaan Gram Sampel 3

d. Sampel 4 (Desa Balamoa)

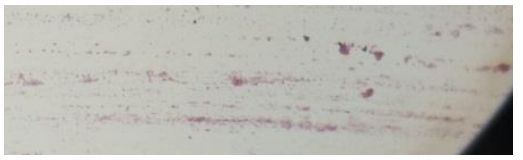

Gambar 4

Hasil Pewarnaan Gram Sampel 4

Dari hasil di atas, semua sampel berwarna merah muda. Artinya semua sampel mengandung bakteri gram negatif. Bakteri E. coli merupakan salah satu bakteri gram negatif.

Pada pewarnaan Gram, bakteri gram negatif akan kehilangan zat pewarna kristal violet setelah dicuci dengan alkohol, dan sewaktu diberi zat pewarna tandingannya yaitu dengan zat pewarna safranin akan tampak berwarna merah. Perubahan warna ini disebabkan karena struktur kimiawi pada dinding sel bakteri tersebut.

Dinding sel bakteri gram negatif mengandung satu atau beberapa lapis peptidoglikan dan membran luar (outer membrane). Peptidoglikan terikat pada lipoprotein pada membran luar. Terdapat daerah periplasma yaitu daerah yang terdapat diatara membran plasma dan membran luar. Periplasma berisi enzim degradasi konsentrasi tinggi serta proteinprotein transpor. Dinding sel bakteri Gram negatif tidak megandung asam teikoat dan karena hanya mengandung sejumlah kecil peptidoglikan, maka dinding sel bakeri Gram negatif lebih rentan terhadap kerusakan mekanis. Inilah yang menyebabkan ketika diberi alkohol pada pengecatan Gram, dinding sel bakteri Gram negatif kehilangan warna, sehingga ketika diberi pewarna safranin akan tampak seperti warna cat terakhir tersebut [6].
3.2 Hasil Uji Kultur Media Blood Agar

a. Sampel 1 (Desa Langgen)

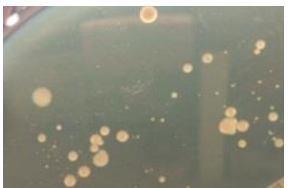

Gambar 5

Hasil kultur BAP Sampel 1

b. Sampel 2 (Desa Debong)

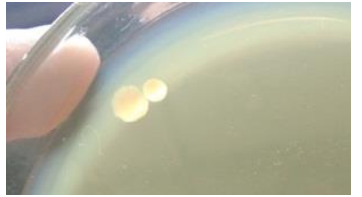

Gambar 6.

Hasil kultur BAP Sampel 2

c. Sampel 3 (Desa Kertayasa)

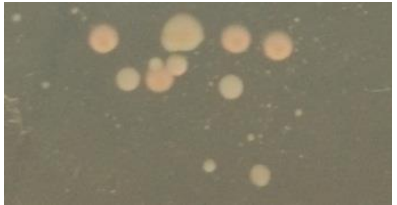

Gambar 7.

Hasil kultur BAP Sampel 3

d. Sampel 4 (Desa Balamoa)

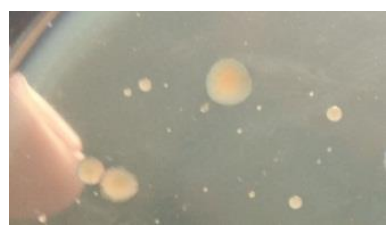

Gambar 8

Hasil kultur BAP Sampel 4

Dari hasil semua sampel menunjukan bahwa koloni terlihat sedang, abu-abu, dan smooth. Ini menunjukan ciri dari bakteri E.coli yang merupakan bakteri gram negatif basil yang tidak memiliki kemampuan untuk menghemolisiskan darah. Hal ini ditandai dengan tidak terjadinya perubahan warna pada daera di dekat koloni bakteri tersebut.

3.3 Hasil Uji Kultur Macconkey Agar

a. Sampel 1 (Desa Langgen)

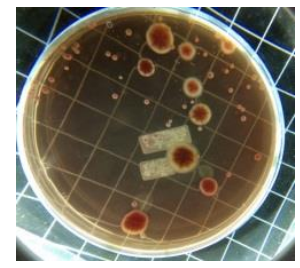

Gambar 9

Hasil Mac conkey Agar Sampel 1 
b. Sampel 2 (Desa Debong)

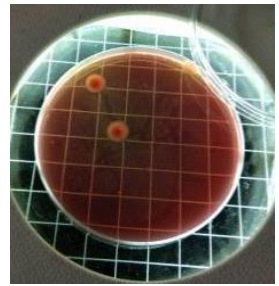

Gambar 10.

Hasil Mac conkey Agar Sampel 2

c. Sampel 3 (Desa Kertayasa)

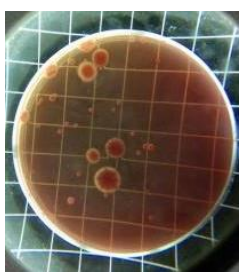

Gambar 11.

Hasil Mac conkey Agar Sampel 3

d. Sampel 4 (Desa Balamoa)

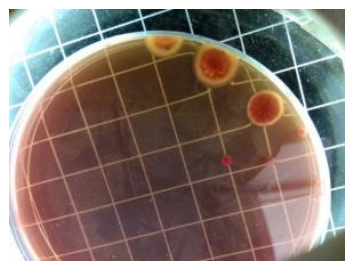

Gambar 12.

Hasil Mac conkey Agar Sampel 4

Berdasarkan hasil kultur, didapatkan koloni bakteri yang tumbuh berukuran sedang, berwarna merah bata yang dikelilingi oleh zonayang sedikit keruh, cembung, halus, dan agak berkabut. Kemungkinan besar karakteristik koloni yang tumbuh tersebut merupakan koloni E.coli dalam agar Mac Conkey. E.coli dalam kultur agar Macconkey memperlihatkan perubahan warna menjadi merah bata menyala dengan zona disekelilingnya yang sedikit lebih keruh. Perubahan warna yang terjadi, disebabkan karena E.coli mampu memfermentasi laktosa sehingga $\mathrm{pH}$ menjadi turun dan mempermudah absorpsi neutral red yang membuat warna menjadi merah. Sementara itu,hasil fermentasi laktosa berupa asam akan bereaksi dengan garam empedu yang dikandung dalam agar Macconkey dan akan membentuk endapan keruh disekitarnya.

Temuan warna merah muda didapatkan karena kemampuan E.coli sebagai bakteri gram negatif memfermentasi laktosa mengakibatkan $\mathrm{pH}$ media bernilai dibawah 6,8 menjadikan media berwarna merah netral namun oleh E. coli warna merah netral tersebut diserap sehingga pada akhirnya yang tersisa nampak pada media berwarna merah muda [7].
Dengan demikian dapat disimpulkan bahwa bakteri yang terkandung pada jamu kunyit asem di beberapa tempat di Kabupaten Tegal mampu memfermentasi laktosa

\section{KESIMPULAN}

Dari hasil identifikasi melalui pewarnaan gram dan kultur menggunakan media Blood Agar Plate (BAP) dan Mac conkey Agar dapat disimpulkan bahwa pada ke empat sampel jamu kunyit asem yag diambil dari beberapa tempat di kabupaten Tegal positif mengandung Bakteri E. coli.

\section{UCAPAN TERIMA KASIH}

Penulis mengucapkan terima kasih yang tak terhingga kepada Allah SWT atas kesempatan dan ijin-Nya sehingga penulis mampu melakukan riset ini serta semua pihak yang telah membantu dalam proses penelitian dari awal hingga akhir

\section{REFERENSI}

[1] Keputusan Menteri Kesehatan RI No.661/MENKES/SK/VII/1994 Tentang Persyaratan Obat Tradisional. Jakarta: DepKes RI; 1994.

[2] Anonim, 2005, Peraturan Kepala Badan Pengawas Obat dan Makanan Republik Idonesia Nomor HK.00.05.4.1380 Tentang Pedoman Cara Pembuatan Obat Tradisional yang Baik, Badan Pengawas Obat dan Makanan Republik Indonesia, Jakarta

[3] Tivani, Inur. 2018. Uji Angka Lempeng Total (ALT) Pada Jamu Gendong Kunyit Asem Di Beberapa Desa di Keamatan Talang. Jurnal PSEJ (Pancasakti Science Education Journal). Volume 3 Nomor 1.

[4] Radji, Maksum. 2016. Mikrobiologi. Jakarta: Penerbit Buku Kedokteran EGC.

[5] Irianto, Koes. 2013. Mikrobiologi Medis. Bandung: Alfabeta.

[6] Pratiwi, Sylvia. 2008. Mikrobiologi Farmasi. Jakarta: Erlangga.

[7] I Made Nugraha Gunamanta Sabudi1 , Made Agus Hendrayana2. 2017. identifikasi bakteri Eschericia coli serotipe ol57 dengan media sorbitol mac conkey agar (smac) pada buah semangka potong dari pedagang buah kaki lima di kota denpasar Volume 6 no. 7. Jurnal Medika 